\title{
Vitamin D deficiency following Billroth II surgery - How much vitamin D is enough?: a case report
}

\author{
Eva Sampl ${ }^{1}$, Doris Wagner ${ }^{2}$, Claudia Friedl ${ }^{1}$, Harald Dobnig ${ }^{3}$, Astrid Fahrleitner-Pammer ${ }^{{ }^{*}}$
}

\begin{abstract}
Background: Vitamin D deficiency with all its consequences is a global health problem.

Case Presentation: We reported a 62-year-old Caucasian woman with alcohol-related liver cirrhosis (Child class A) and a medical history of Billroth II surgery. Although she has taken an oral dose of $16800 \mathrm{IU}$ vitamin D daily for six weeks to normalise her 25-hydroxyvitamin D level the raise was only moderate.

Conclusion: High-dose oral or parenteral vitamin D therapy is necessary to gain sufficient 25 -hydroxyvitamin $D$ serum levels in patients following gastric surgery.
\end{abstract}

\section{Background}

Vitamin D deficiency is defined as 25-hydroxyvitamin D serum levels below $20 \mathrm{ng} / \mathrm{ml}$; levels $\geq 20$ and $<30 \mathrm{ng} / \mathrm{ml}$ indicate an inadequate vitamin D status. Approximately 1 billion people worldwide have 25-hydroxyvitamin $\mathrm{D}$ levels below $30 \mathrm{ng} / \mathrm{ml}[1]$. The major source of vitamin $\mathrm{D}$ is sunlight, which promotes subcutaneous production of vitamin D under the influence of UVB light; only 15$20 \%$ of vitamin D in the body derives from food. Apart from musculoskeletal malfunction (eg. osteomalacia, osteoporosis, muscle weakness, falls), vitamin D deficiency seems to be associated with several other diseases, e.g. cancer and cardiovascular or immunological disorders[2]. Corresponding trials demonstrated that a daily vitamin D intake of $800-1000$ IU is needed to achieve and maintain 25-hydroxyvitamin D levels between $70-80 \mathrm{nmol} / \mathrm{l}$, which are considered to be optimal for fracture prevention[3].

\section{Case Presentation}

A 62-year-old female Caucasian was admitted to our endocrinology outpatient clinic for evaluation of osteoporosis. The patient had a history of partial gastrectomy with Billroth II reconstruction due to multiple gastric ulcers 27 years previously, and liver cirrhosis (Child A) of more than 15 years' standing due to a period of alcoholism as well as local breast cancer in 2003. For

\footnotetext{
* Correspondence: astrid.fahrleitner@medunigraz.at

'Department of Internal Medicine, Division of Endocrinology and Nuclear Medicine, Medical University Graz, Auenbruggerplatz 15, Graz, 8036, Austria
}

treatment of portal hypertension and recurrent ascites, she was being treated with propranolol, furosemide and spironolactone.

A fasting blood sample taken the morning after admission produced the following results: elevated liver transaminases (GGT $242 \mathrm{U} / 1[<38]$, AST $49 \mathrm{U} / \mathrm{l}[<30]$ ), but unimpaired liver function. Blood count and other parameters were within normal limits. Specific analysis showed low 25-hydroxyvitamin D (20 ng/ml [30.0-60.0]) with normal serum PTH, but elevated levels of bonespecific alkaline phosphatase $(74.3 \mu \mathrm{g} / \mathrm{l}$ [7.1-21.3]) and $\beta$-Crosslaps $(0.53 \mathrm{ng} / \mathrm{ml}[0.09-0.44])$, reflecting accelerated bone turnover. Standardized $\mathrm{x}$-ray of the spine showed hyperkyphosis but no fractures. DXA measurement at the spine and the hip revealed osteopenia with a T-score of $-1.8 \mathrm{SD}$ and $-2.0 \mathrm{SD}$, and osteoporosis at the distal forearm with a T-score of $-2.8 \mathrm{SD}$.

The patient was advised to take an oral dose of 16000 IU (40 drops) of vitamin D 3 per week combined with a daily supplement of $1000 \mathrm{mg}$ calcium and $800 \mathrm{IU}$ vitamin D 3.

At 6 weeks' follow-up, she reported that she had taken 40 drops of vitamin D 3 daily, resulting in a cumulative intake of $705600 \mathrm{IU}$ in that period. Blood analysis then showed $35 \mathrm{ng} / \mathrm{ml} 25$-hydroxyvitamin $\mathrm{D}$, with a surprisingly small increase of $15 \mathrm{ng} / \mathrm{ml}$.

\section{Discussion}

Oral treatment with 1000 IU vitamin D daily over a period of 3-4 months raises 25-hydroxyvitamin D by about 
$10 \mathrm{ng} / \mathrm{ml}[4]$. Based on this, an increase of $168 \mathrm{ng} / \mathrm{ml}$ would be expected with a daily vitamin $\mathrm{D}$ intake of 16 $800 \mathrm{IU}$. The increase of just $15 \mathrm{ng} / \mathrm{ml}$ was a surprise. The history of Billroth II may, however, have had a negative impact on absorption, although the enteral absorption of the fat-soluble vitamin $\mathrm{D}$ takes place in the duodenum and the proximal jejunum, sections of the gut that are not removed as part of a Billroth II resection.

The exact mechanism of the development of vitamin $\mathrm{D}$ deficiency in patients following gastric surgery is not yet known. Malabsorption due to accelerated intestinal passage, impaired secretion of pancreatic enzymes and bacterial overgrowth may lead to steatorrhea [5] and so to avoidance of food rich in vitamin $\mathrm{D}$, which could also contribute to vitamin $\mathrm{D}$ deficiency[6].

\section{Conclusion}

Vitamin D toxicity has recently become a controversial issue. According to the literature, a vitamin D intake of 10000 IU daily does not cause intoxication in the sense of 25 -hydroxyvitamin D levels above $150 \mathrm{ng} / \mathrm{ml}$ associated with hypercalcemia and hyperphosphatemia, even in healthy people[1,7]. Some special groups of patients may need even higher doses of supplementation to achieve satisfactory serum vitamin D levels. This case demonstrates that patients with a history of gastrointestinal surgery may need either high-dose oral vitamin D supplementation or even parenteral administration.

\section{Consent}

Written informed consent was obtained from the patient for publication of this case report and accompanying images. A copy of the written consent is available for review by the Editor-in-Chief of this journal.

\footnotetext{
Abbreviations

GGT: gamma glutamyl-transferase; AST: aspartate transaminase; PTH: parathyroid hormone; DXA: dual-energy x-ray absorptiometry.
}

\section{Acknowledgements}

The authors want to thank Prof. Barbara Obermayer-Pietsch and her team for the laboratory analysis.

\section{Author details}

${ }^{1}$ Department of Internal Medicine, Division of Endocrinology and Nuclear Medicine, Medical University Graz, Auenbruggerplatz 15, Graz, 8036, Austria. ${ }^{2}$ Department of Surgery, Division of Transplantation Surgery, Medical University Graz, Auenbruggerplatz 29, Graz, 8036, Austria. ${ }^{3}$ Department of Internal Medicine, Division of Endocrinology and Nuclear Medicine, Medical University Graz, Auenbruggerplatz 29, Graz, 8036, Austria.

\section{Authors' contributions}

ES and CF collected the patient data, performed literature search and were contributors in writing this manuscript. DW supervised the patient within her liver disease and analyzed the patient data. HD and AFP were responsible for the management of the patient and revised the manuscript critically for important intellectual content. All authors read and approved the final manuscript.

\section{Competing interests}

The authors declare that they have no competing interests.

Received: 15 October 2009

Accepted: 8 January 2010 Published: 8 January 2010

\section{References}

1. Holick MF: Vitamin D Deficiency. N Engl J Med 2007, 357:266-281.

2. Holick MF: High Prevalence of Vitamin D Inadequacy and Implications for Health. Mayo Clin Proc 2006, 81(3):353-373.

3. Dawson-Hughes B, Heaney RP, Holick MF, Lips P, Meunier PJ, Vieth R: Estimates of optimal vitamin D status. Osteoporos Int 2005, 16:713-716.

4. Cannell JJ, Hollis BW: Use of Vitamin D in Clinical Practice. Altern Med Rev 2008, 13(1):6-20.

5. Thieler S, Schölmerich J: Gastrointestinale Erkrankungen und Osteomalazie. Internist 2008, 49:1197-1205.

6. Tovey Fl, Hobsley M: Post-gastrectomy patients need to be followed up for 20-30 years. World J Gastroenterol 2000, 6(1):45-48.

7. Vieth $\mathrm{R}$ : Why the optimal requirement for vitamin D3 is probably much higher than what is officially recommended for adults. J Steroid Biochem Mol Biol 2004, 89-90:575-579.

doi:10.1186/1757-1626-3-12

Cite this article as: Sampl et al:: Vitamin D deficiency following Billroth II surgery - How much vitamin D is enough?: a case report. Cases Journal 2010 3:12.

\section{Submit your next manuscript to BioMed Central and take full advantage of:}

- Convenient online submission

- Thorough peer review

- No space constraints or color figure charges

- Immediate publication on acceptance

- Inclusion in PubMed, CAS, Scopus and Google Scholar

- Research which is freely available for redistribution 